\title{
PERAN BADAN NARKOTIKA NASIONAL KABUPATEN BLITAR DALAM MEWUJUDKAN MASYARAKAT KABUPATEN BLITAR BEBAS NARKOBA
}

\author{
Karyoto ${ }^{1}$, Defi Aprilia ${ }^{2}$ \\ 1. Universitas Islam Kadiri \\ 2. SMP Lab. Universitas Negeri Malang \\ email:apriliadefi53@gmail.com
}

\begin{abstract}
ABSTRAK
Narkoba adalah bahan atau zat yang dapat mempengaruhi kondisi kejiwaan seseorang baik pikiran, perasaan, maupun perilaku serta dapat menyebabkan ketergantungan fisik dan psikologi. Pemakaian narkoba yang disalahgunakan dan tidak sesuai dengan standar dapat mengakibatkan kerugian bagi individu atau masyarakat. Menurut Kepala BNN Kabupaten Blitar AKBP. Agustianto, SH.,MH menyampaikan. Sesuai data Polres Blitar selama tahun 2016 sebanyak 60 pelaku peredar narkoba telah diamankan. Sementara itu, $32 \%$ pengguna narkoba adalah kalangan pelajar, sehingga kondisi ini harus benar-benar menjadi perhatian semua pihak untuk memutus mata rantai peredaran narkoba. Penelitian ini bertujuan untuk mengetahui peran Badan Narkotika Nasional Kabupaten Blitar dalam Mewujudkan Masyarakat Kabupaten Blitar Bebas Narkoba. Penelitian ini menggunakan metode penelitian sosiologis empiris. Sumber data primer yang dijadikan informan yaitu pihak BNN Kabupaten Blitar dan sasaran kegiatan BNN Kabupaten Blitar. Teknik pengumpulan data yang digunakan adalah observasi,wawancara, dan dokumentasi. Analisis data dengan menggunakan reduksi data, penyajian data, dan penarikan kesimpulan. Berdasarkan penelitian yang dilakukan, diperoleh simpulan hasil sebagai berikut. Peran Badan Narkotika Nasional Kabupaten Blitar dalam upaya pencegahan antara lain melalui diseminasi informasi dan advokasi pada masyarakat di Kabupaten Blitar terutama di wilayah yang termasuk daerah rawan akan adanya penyalahgunaan dan peredaran gelap narkoba. Peran Badan Narkotika Nasional Kabupaten Blitar dalam upaya pemberdayaan masyarakat antara lain melalui pemberdayaan yang berbasis pada peran aktif masyarakat. Peran Badan Narkotika Nasional Kabupaten Blitar dalam upaya pemberantasan yaitu upaya pemberantasan melalui kegiatan analisis intelegen produk, kegiatan upaya pemberantasan melalui analisis intelegen taktis, dan kegiatan upaya pemberantasan melalui pemetaan jaringan.

Kata Kunci : BNN Kabupaten Blitar ; Bebas Narkoba
\end{abstract}

\section{ABSTRACT}

Drugs are substances or substances that can affect the psychological condition of a person's thoughts, feelings, and behavior and can cause physical and psychological dependence. Use of drugs that are abused and not in accordance with the standards may result in harm to individuals or communities. According to Head of BNN Kabupaten Blitar AKBP. Agustianto, SH., MH conveyed. Appropriate data Blitar Police during 2016 as many as 60 drug offenders have been secured. Meanwbile, $32 \%$ of drug users are among the students, so this condition should really be the concern of all parties to break the chain of drugs circulation. This study aims to determine the role of National Narcotics Agency Blitar District in Creating Blitar Community Free Drugs. This research uses empirical sociological research method. Primary data source that made the informant is BNN Blitar and the target of BNN Blitar Regency. Data collection techniques used are observation, interview, and documentation. Data analysis using data reduction, data presentation, and conclusion. Based on the research conducted, obtained the following results conclusion. The role of the National Narcotics Agency of Blitar Regency in prevention efforts, among others through dissemination of information and advocacy on the community in Blitar regency, especially in areas including areas prone to abuse and illicit drug trafficking. The role of National Narcotics Agency of Blitar Regency in the effort of community empowerment is through empowerment based on the active role of the community. The role of the National Narcotics Agency of Blitar Regency in eradication efforts is the eradication effort through product intelligence analysis activities, eradication efforts through tactical intelligence analysis, and eradication activities through network mapping.

Keywords: BNN Blitar Regency ; Drug-Free 


\section{A. PENDAHULUAN}

Narkoba atau yang disingkat dengan Narkotika, Psikotropika dan Bahan Adiktif adalah sesuatu yang sudah tidak asing didengar oleh telinga masyarakat Indonesia. Narkoba adalah bahan atau zat yang dapat mempengaruhi kondisi kejiwaan seseorang baik pikiran, perasaan, maupun perilaku serta dapat menyebabkan ketergantungan fisik dan psikologi.

Pemakaian narkoba yang disalahgunakan dan tidak sesuai dengan standar dapat mengakibatkan kerugian bagi individu atau masyarakat. Dan lebih merugikan lagi jika disertai dengan penyalahgunaan dan peredaran gelap narkoba yang membahayakan kehidupan berbangsa dan bernegara serta memperlemah ketahanan nasional.

Berdasarkan Data Pusat Penelitian Kesehatan (Puslitkes) Universitas Indonesia menyebutkan bahwa angka prevelensi penyalahgunaan narkotika di Jawa Timur mencapai 2,01 persen atau sekitar 568.304 orang dalam usia 10-59 tahun.

Kepala Badan Narkotika Nasional Provinsi (BNNP) Jawa Timur, Brigadir Jendral Polisi Fatkhur Rahman mengungkapkan bahwa dari data BNNP 20\% pengguna narkoba adalah pelajar.

Menurut Kepala BNN Kabupaten Blitar AKBP. Agustianto, SH.,MH menyampaikan. Sesuai data Polres Blitar selama tahun 2016 sebanyak 60 pelaku peredar narkoba telah diamankan. Sementara itu, $32 \%$ pengguna narkoba adalah kalangan pelajar, sehingga kondisi ini harus benar-benar menjadi perhatian semua pihak untuk memutus mata rantai peredaran narkoba.

Berdasarkan pasal 64 ayat (1) UndangUndang 35 Tahun 2009 tentang Narkotika. Dalam rangka pencegahan dan pemberantasan penyalahgunaan dan peredaran gelap Narkotika dan Prekusor Narkotika, dengan undang-undang ini dibentuk Badan Narkotika Nasional, yang selanjutnya disingkat $\mathrm{BNN}$.

BNN berkedudukan di ibu kota negara, BNN Provinsi berkedudukan di ibu kota provinsi, dan BNN Kabupaten/ Kota berkedudukan di ibu kota kabupaten/ kota. Dalam melaksanakan tugas pemberantasan penyalahgunaan dan peredaran gelap Narkotika, BNN berwenang melakukan penyelidikan dan penyidikan penyalahgunaan dan peredaran gelap Narkotika dan Presekutor Narkotika. Dengan kedudukan BNN tersebut maka secara yuridis telah memberikan perlindungan kepada masyarakat agar tidak terjerumus pada jurang narkoba.

Berdasarkan latar belakang diatas maka penulis berkeinginan untuk mengetahui bagaimana peran Badan Narkotika Nasional Kabupaten Blitar dalam melaksanakan program Pencegahan dan Pemberantasan Penyalahgunaan dan Pengerdaran Gelap Narkoba (P4GN) untuk mewujudkan generasi bangsa bebas narkoba.

\section{Landasan Teori}

\section{Pengertian Narkoba}

Secara harfiah menurut Arifin (2007) narkoba atau napza adalah bahan / zat yang dapat mempengaruhi kondisi kejiwaan /psikologi seseorang ( pikiran, perasaan, dan perilaku) serta dapat menimbulkan ketergantungan fisik dan psikologi.

\section{Penyalahgunaan Narkoba}

Menurut Ma'roef (1986) secara etimoligi, penyalahgunaan itu sendiri dalam Bahasa asingnya disebut abuse yaitu memakai hak miliknya yang bukan pada tempatnya. Dapat juga diartikan salah pakai atau misuse yaitu mempergunakan sesuatu yang tidak sesuai dengan fungsinya.

\section{Faktor Penyebab Penyalahgunaan Narkoba}

Menurut Subagyo Partodihardjo terdapat beberapa alasan orang memakai narkoba, yaitu:

a) Ingin kenikmatan yang cepat

b) Ketidaktahuan

c) Alasan Internal

d) Alasan Keluarga

e) Alasan orang lain

f) Jaringan peredaran luas sehingga narkoba mudah di dapat

\section{Kinerja Badan Narkotika Nasional}

Sesuai pasal 64 Undang-Undang nomor 35 Tahun 2009 menyatakan bahwa dalam rangka pencegahan dan pemberantasan penyalahgunaan dan peradaran narkotika, dengan UndangUndang ini dibentuk Badan Narkotika Nasional, yang disingkat $\mathrm{BNN}$.

Menurut Sofyan (2007) peran Badan Narkotika Nasional yaitu :

a) Mendorong gerakan masyarakat untuk peduli dalam upaya anti Narkoba

b) Mengumpulkan data, memantau dan mengevaluasi

c) Operasional. Membantu penegak hukum menjalankan tugasnya atas Arahan atau izin dari polisi.

d) Fasilitas. Memberikan bantuan yang diperlukan oleh masyarakat 
Tugas, Fungsi, dan Kewenangan Badan Narkotika Nasional

Pada Peraturan Kepala Badan Narkotika Nasional Nomor 3 Tahun 2015 tentang Organisasi dan Tata Kerja Badan Narkotika Nasional Provinsi dan Badan Narkotika Nasional Kabupaten/Kota Pasal 23 yaitu BNNK/Kota mempunyai tugas melaksanakan tugas, fungsi, dan wewenang BNN dalam wilayah Kabupaten/Kota.

Peraturan Kepala Badan Narkotika Nasional Nomor 3 Tahun 2015 tentang Organisasi dan Tata Kerja Badan Narkotika Nasional Provinsi dan Badan Narkotika Nasional Kabupaten/Kota di jelaskan mengenai Fungsi Badan Narkotika Nasional Kabupaten/Kota (BNNK/Kota) Pasal 24 yaitu :

BNNK/Kota menyelenggarakan fungsi:

a) Pelaksanaan koordinasi penyusunan rencana strategis dan rencana kerja tahunan di bidang P4GN dalam wilayah Kabupaten/Kota

b) Pelaksanaan kebijakan teknis di bidang pencegahan, pemberdayaan masyarakat, rehabilitasi dan pemberantasan dalam wilayah Kabupaten/Kota

c) Pelaksanaan layanan hukum dan kerja sama dalam wilayah Kabupaten/Kota

d) Pelaksanaan koordinasi dan kerja sama P4GN dengan instansi pemerintah terkait dan komponen masyarakat dalam wilayah Kabupaten/Kota

e) Pelayanan administrasi BNNK/Kota

f) Pelaksanaan evaluasi dan pelaporan BNNK/Kota

\section{B. METODE PENELITIAN}

Penelitian ini menggunakan metode penelitian sosiologis empiris. Hal ini didasarkan bahwa peneliti ingin mengetahui Peran Badan Narkotika Kabupaten Blitar dalam Mewujudkan Masyarakat Kabupaten Blitar Bebas Narkoba. Lokasi penelitian bertempat di Kantor BNN Kabupaten Blitar. Sumber data primer yang dijadikan informan yaitu pihak BNN Kabupaten Blitar dan sasaran kegiatan BNN Kabupaten Blitar. Teknik pengumpulan data yang digunakan dalam penelitian ini adalah observasi,wawancara, dan dokumentasi. Sedangkan analisis data dengan menggunakan reduksi data, penyajian data, dan penarikan kesimpulan.

\section{Gambar 1 Analisis Data Interaktif}

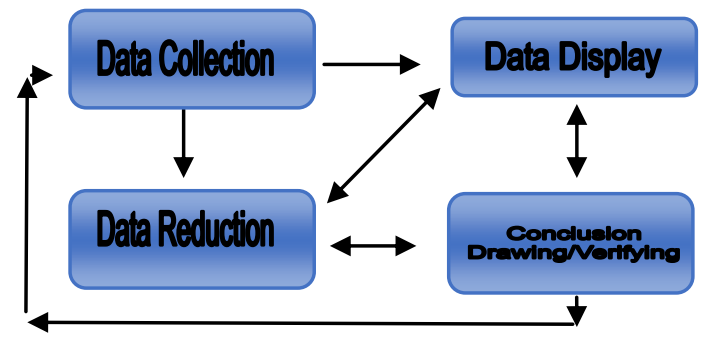

\section{HASIL DAN PEMBAHASAN}

\section{Peran Badan Narkotika Nasional Kabupaten Blitar dalam Upaya Pencegahan dan Pemberdayaan Masyarakat untuk Mewujudkan Masyarakat Kabupaten Blitar Bebas Narkoba}

Kegiatan yang dilakukan oleh Badan Narkotika Nasional Kabupaten Blitar dalam upaya pencegahan antara lain dengan dua cara yaitu, diseminasi informasi dan advokasi. Upaya pencegahan melalui kegiatan diseminasi informasi dilakukan dengan tiga cara antara lain : (1) Kegiatan diseminasi informasi melalui media cetak, (2) Kegiatan diseminasi informasi melalui media elektronik, (3) Kegiatan diseminasi infomasi melalui tatap muka langsung. Upaya pencegahan melalui kegiatan advokasi dilakukan melalui beberapa kegiatan antara lain: (1) Kegiatan advokasi pada instansi pemerintah, (2) Kegiatan advokasi pada instansi pendidikan, (3) Kegiatan Advokasi pada Instansi Swasta, (4) Kegiatan Advokasi pada Lingkungan Masyarakat. Paparan tentang kegiatan yang dilakukan dalam upaya pencegahan yang dilakukan oleh BNN Kabupaten Blitar sesuai dengan Peraturan Kepala Badan Narkotika Nomor 3 Tahun 2015 tentang Organisasi dan Tata Kerja Badan Narkotika Nasional Provinsi dan Badan Narkotika Nasional Kabupaten/Kota yaitu : Pasal 24 (b) Dalam melaksanakan tugas BNNK/Kota menyelenggrakan fungsi pelaksanaan kebijakan teknis di bidang pencegahan, pemberdayaan masyarakat, rehabilitasi dan pemberantasan dalam wilayah Kabupaten/Kota. Pasal 28 Seksi Pencegahan dan Pemberdayaan Masyarakat mempunyai tugas melakukan penyiapan bahan pelaksanaan koordinasi penyusunan rencana strategis dan rencana kerja tahunan P4GN, kebijakan teknis P4GN, diseminasi informasi dan advokasi, pemberdayaan alternatif dan peran serta masyarakat, dan evaluasi dan pelaporan di bidang pencegahan dan pemberdayaan masyarakat dalam wilayah Kabupaten/ Kota. 
Kerjasama dalam rangka pelaksanaan upaya pencegahan dengan Instansi terkait. Dalam pelaksanaan upaya pencegahan secara diseminasi informasi dan advokasi BNN Kabupaten Blitar melakukan kerjasama dengan instansi terkait seperti : (1) kelompok sasaran program antara lain instansi pemerintah, pendidikan, swasta, dan masyarakat (2) media elektronik, dan (3) media cetak. Dari paparan diatas mengenai kerjasama yang dilakukan oleh BNN Kabupaten Blitar dengan instansi terkait dalam pelaksanaan upaya pencegahan sesuai dengan Peraturan Kepala Badan Narkotika Nomor 3 Tahun 2015 tentang Organisasi dan Tata Kerja Badan Narkotika Nasional Provinsi dan Badan Narkotika Nasional Kabupaten/Kota yaitu : Pasal 24 BNNK/Kota menyelenggarakan fungsi pelaksanaan koordinasi dan kerja sama P4GN dengan instansi pemerintah terkait dan komponen masyarakat dalam wilayah Kabupaten/Kota. Pasal 38 ayat (1) Fungsi kooordinasi dalam bidang P4GN dilaksanakan melalui koordinasi dengan pimpinan lembaga pemerintah baik Provinsi maupun Kabupaten/Kota, komponen masyarakat, dan pihak lain yang dipandang perlu. Pasal 38 ayat (2) b Kerjasama sesuai dengan bidang tugas dan fungsi masing-masing dalam pelaksanaan kebijakan di bidang P4GN.

Dalam pelaksanaan upaya pencegahan terdapat beberapa hambatan yang dialami. Hambatan yang dialami dalam pelaksanaan upaya pencegahan antara lain : (1) Adanya ketakutan yang dialami oleh masyarakat, (2) Pembatasan waktu dalam penyampaian materi dan penundaan waktu pelaksanaan kegiatan, (3) Sarana dan prasarana yang terbatas.

Hambatan yang dialami oleh BNN Kabupaten Blitar jika terus menerus berlangsung akan menggangu kegiatan dalam upaya pencegahan, oleh karenanya BNN Kabupaten Blitar melakukan upaya penyelesaian dengan beberapa cara antara lain : (1) Sosialisasi mengenai tujuan dan fungsi BNN Kabupaten Blitar, (2) Melakukan pendekatan kepada masyarakat, (3) Bekerjasama dengan panitia kegiatan, (4) Penggunaan sarana pribadi pelaksana kegiatan.

Kegiatan yang dilakukan oleh Badan Narkotika Nasional Kabupaten Blitar dalam upaya pemberdayaan masyarakat adalah tindak lanjut dari upaya pencegahan. Setelah kegiatan upaya pencegahan terlaksana, lalu dilanjutkan dengan upaya pemberdayaan guna memberikan dukungan terhadap rencana kegiatan yang akan dilaksanakan oleh masyarakat. Sehingga upaya BNN Kabupaten Blitar tidak berhenti pada pencegahan. Upaya pemberdayaan masyarakat yang dilakukan oleh BNN Kabupaten Blitar dilakukan dengan pemberdayaan yang berbasis pada peran aktif masyarakat yaitu pemberdayaan yang berbasis pada peran aktif masyarakat. Macam-macam upaya pemberdayaan masyarakat diuraikan sebagai berikut : (1) Pelatihan untuk kader anti penyalahgunaan narkoba, (2) Pemberian dana untuk pelaksanaan kegiatan masyarakat, (3) Tes urine. Upaya pemberdayaan yang telah dilaksanakan oleh BNN Kabupaten Blitar telah sesuai dengan Undang-Undang Republik Indonesia Nomor 35 Tahun 2009 pasal 70 (e) yaitu : BNN mempunyai tugas memberdayakan masyarakat dalam pencegahan penyalahgunaan dan peredaran gelap Narkotika dan Presekusor Narkotika.

Upaya pemberdayaan masyarakat yang dilaksanakan BNN Kabupaten Blitar tidak terlepas dari kerjasama dengan instansi terkait. Kerjasama tersebut dilakukan bersama dengan instansi pemerintah, pendidikan, swasta, dan masyarakat. Selain itu BNN Kabupaten Blitar juga bekerjasama dengan media cetak dan elektronik agar kegiatan dapat diketahui oleh khalayak luas terutama masyarakat Kabupaten Blitar. Hubungan kerjasama yang dibangun oleh BNN Kabupaten Blitar bersama instansi terkait dalam upaya pemberdayaan masyarakat sesuai dengan Peraturan Kepala Badan Narkotika Nasional Nomor 3 Tahun 2015 tentang Organisasi dan Tata Kerja Badan Narkotika Nasional Provinsi dan Badan Narkotika Nasional Kabupaten/ Kota pasal 38 ayat (1) yaitu : Fungsi koordinasi dalam bidang P4GN dilaksanakan melalui koordinasi dengan pimpinan lembaga pemerintah baik Provinsi maupun Kabupaten/Kota, komponen masyarakat, dan pihak lain yang dipandang perlu.

Pelaksanaan upaya pemberdayaan masyarakat yang dilakukan oleh BNN Kabupaten Blitar masih mengalami hambatan yaitu kecurangan yang dilakukan oleh peserta tes urine. Kecurangan tersebut antara lain dilakukan melalui pertukaran urine dengan peserta lainnya, mengisi gelas tempat urine dengan air.

Hambatan yang terjadi pada pelaksanaan upaya pemberdayaan masyarakat yang dilaksanakan oleh BNN Kabupaten Blitar harus mendapatkan solusi dan penanganan. Hal ini dilakukan agar hambatan yang terjadi tidak menjadi faktor kegagalan dalam upaya pemberdayaan masyarakat. Upaya penyelesaian hambatan tersebut antara lain : (1) Mengadakan operasi dadakan, (2) Penjagaan pada pelaksanaan tes urine yang diperketat. 


\section{Peran Badan Narkotika Nasional Kabupaten Blitar dalam Upaya Pemberantasan Penyalahgunaan Narkoba untuk Mewujudkan Masyarakat Kabupaten Blitar Bebas Narkoba}

Kegiatan yang dilakukan oleh Badan Narkotika Nasional Kabupaten Blitar dalam upaya pemberantasan antara lain dengan tiga cara yaitu, (1) kegiatan upaya pemberantasan analisis intelegen produk, (2) kegiatan upaya pemberantasan analisis intelegen taktis, dan (3) kegiatan upaya pemberantasan pemetaan jaringan.

Upaya pemberantasan melalui analisis intelegen produk adalah proses penerimaan laporan kasus peredaran gelap narkoba yang diperoleh dari berbagai sumber. Analisis intelegen produk berfungsi untuk menerima informasi dari berbagai sumber yang berkenaan mengenai informasi peredaran gelap narkoba. Upaya pemberantasan melalui analisis intelegen produk yang dilakukan oleh BNN Kabupaten Blitar sesuai dengan Peraturan Kepala Badan Narkotika Nasional Nomor 3 Tahun 2015 Tentang Organisasi dan Tata Kerja Badan Narkotika Nasional Provinsi dan Badan Narkotika Nasional Kabupaten/Kota Pasal 39 Dalam rangka P4GN, BNNP dan BNNK/Kota melakukan siaga informasi 24 (dua puluh empat) jam di bidang P4GN.

Upaya pemberantasan melalui analisis intelegen taktis adalah tahap lanjutan dari analisis intelegen produk. Analisis intelegen taktis adalah proses cek lapangan dari informasi yang telah didapatkan oleh BNN Kabupaten Blitar. Cek lapangan yang dilakukan bertujuan untuk mendapatkan informasi yang lebih jelas dan lengkap tentang jaringan peredaran gelap narkoba. Upaya pemberantasan melalui analisis intelegen taktis sesuai dengan UU Nomor 35 Tahun 2009 tentang Narkotika Pasal 75 (a) bahwa dalam rangka melakukan penyelidikan, penyidik BNN berwenang melakukan penyelidikan atas kebenaran laporan serta keterangan tentang adanya penyalahgunaan dan peredaran gelap narkotika da prekursor narkotika. Upaya pemberantasan penyalahgunaan narkoba melalui pemetaan jaringan adalah upaya yang dilakukan oleh BNN Kabupaten Blitar yakni pengumpulan informasi jaringan peredaran gelap narkoba. Pemetaan jaringan yaitu mengumpulkan informasi yang diperoleh yang selanjutnya diolah menjadi satu. Upaya pemberantasan melalui pemetaan jaringan yang dilakukan oleh BNN Kabupaten Blitar sesuai dengan Peraturan Kepala Badan Narkotika Nasional Nomor 3 Tahun 2015 Tentang Organisasi dan Tata Kerja Badan Narkotika Nasional Provinsi dan Badan Narkotika Nasional Kabupaten/Kota Pasal 30 Seksi Pemberantasan mempunyai tugas melakukan penyiapan bahan pelaksanaan koordinasi penyusunan rencana strategis dan rencana kerja tahunan, kebijakan teknis P4GN, administrasi penyelidikan dan penyidikan terhadap tindak pidana narkotika, pengawasan distribusi presekusor sampai pada penggunaan akhir, dan evaluasi dan pelaporan di bidang pemberantasan dalam wilayah Kabupaten/Kota. Pasal 39 ayat 2 BNNP dan/atau BNNK/Kota segera mengambil langkah-langkah yang diperlukan serta melaksanakan tindak awal untuk pemberantasan dan pemutusan jaringan kejahatan terorganisasi penyalahgunaan dan peredaran gelap narkotika, psikotropika, presekusor dan bahan adiktif lainnya kecuali bahan adiktif untuk tembakau dan alcohol yang terjadi di wilayah setempat sesuai prosedur yang ditetapkan.

Dalam pelaksanaan upaya pemberantasan BNN Kabupaten Blitar bekerjasama dengan pihak terkait antara lain dengan : (a) Polres Blitar, (b) Kejaksaan, (c) Lembaga Pemsyarakatan, (d) Pengadilan, (e) Dinas Kependudukan dan Catatan Sipil. Kerjasama yang dijalin oleh BNN Kabupaten Blitar dengan berbagai instansi dalam melaksanakan upaya pemberantasan sesuai dengan Peraturan Kepala Badan Narkotika Nasional Nomor 3 Tahun 2015 tentang Organisasi dan Tata Kerja Badan Narkotika Nasional Provinsi dan Badan Narkotika Nasional Kabupaten/Kota Pasal 38 ayat (1) Fungsi koordinasi dalam bidang P4GN dilaksanakan melalui koordinasi dengan pimpinan lembaga pemerintah baik provinsi maupun Kabupaten/Kota, komponen masyarakat dan pihak lain yang dipandang perlu.

Hambatan yang dialamai pada saat pelaksanaan upaya pemberantasan oleh BNN Kabupaten Blitar antara lain : (1) Terbatasnya anggota seksi pemberantasan, (2) Sarana dan prasarana yang belum memadai, (3) Cakupan wilayah yang luas, (d) Terbatasnya kewenangan yang dimiliki.

Hambatan yang dialami oleh BNN Kabupaten Blitar jika terus menerus berlangsung akan menggangu kegiatan dalam upaya pemberantasan, oleh karenanya BNN Kabupaten Blitar melakukan upaya penyelesaian dengan beberapa cara antara lain : (1) Bekerja secara bersama, (2) Penggunaan sarana pribadi 
pelaksana kegiatan, (3) Menguuslkan untuk penambahan personil, (4) Koordinasi rutin.

\section{Indikator Keberhasilan Pencapaian Kinerja Badan Narkotika Nasional Kabupaten Blitar}

Keberhasilan pencapaian kinerja oleh BNN Kabupaten Blitar tidak dapat dilihat berdasarkan dari bebasnya masyarakat Kabupaten Blitar dari narkoba, karena narkoba pada dasarnya dibutuhkan pada kegiatan ilmu pengetahuan dan pengobatan. Pencegahan, pemberdayaan, dan pemberantasan yang dilakukan BNN Kabupaten Blitar adalah penyalahgunaan dan peredaran gelap narkoba. BNN Kabupaten Blitar mengelompokkan indikator keberhasilan pencapaian kinerja antaralain: (1) Kesadaran dan kepedulian masyarakat Kabupaten Blitar tentang bahaya narkoba, (2) Peran masyarakat dalam meningkatkan daya tangkal terhadap pengaruh buruk penyalahgunaan narkoba di Kabupaten Blitar, (3) Adanya kepercayaan masyarakat terhadap BNN Kabupaten Blitar.

\section{KESIMPULAN}

Hasil penelitian yang diperoleh dari penelitian ini adalah (1) Peran Badan Narkotika Nasional Kabupaten Blitar dalam upaya pencegahan antara lain melalui diseminasi informasi dan advokasi pada masyarakat di Kabupaten Blitar terutama di wilayah yang termasuk daerah rawan akan adanya penyalahgunaan dan peredaran gelap narkoba. Dalam rangka pelaksanaan upaya pencegahan BNN Kabupaten Blitar bekerjasama dengan berbagai instansi antara lain kelompok sasaran program upaya pencegahan, media elektronik, dan media cetak. (2) Peran Badan Narkotika Nasional Kabupaten Blitar dalam upaya pemberdayaan masyarakat antara lain melalui pemberdayaan yang berbasis pada peran aktif masyarakat. Dalam rangka upaya pemberdayaan masyarakat BNN Kabupaten Blitar menjalin kerjasama dengan instansi terkait antara lain sasaran program pemberdayaan masyarakat, media elektronik, dan media cetak. Pada pelaksanaan upaya pemberdayaan masyarakat terdapat hambatan yaitu kecurangan yang dilakukan oleh peserta tes urine. Kecurangan tersebut antara lain dilakukan melalui pertukaran urine oleh peserta lain, mengisi gelas tempat urine dengan air. Penyelesaian hambatan yang dilakukan oleh BNN Kabupaten Blitar agar upaya pemberdayaan masyarakat berhasil yaitu mengadakan operasi dadakan dan penjagaan pada pelaksanaan tes urine yang diperketat. (3) Peran Badan Narkotika Nasional Kabupaten Blitar dalam upaya pemberantasan yaitu upaya pemberantasan melalui kegiatan analisis intelegen produk, kegiatan upaya pemberantasan melalui analisis intelegen taktis, dan kegiatan upaya pemberantasan melalui pemetaan jaringan. Dalam rangka upaya pemberantasan BNN Kabupaten Blitar bekerjasama dengan instansi terkait antara lain Polres Blitar, Lembaga Pemasyarakatan, Kejaksanaan Negeri Blitar, Pengadilan Negeri Blitar, dan Dinas Kependudukan dan Catatan Sipil. Hambatan dalam proses upaya pemberantasan yang dilakukan BNN Kabupaten Blitar yakni terbatasnya anggota seksi pemberantasan, sarana dan prasarana yang belum memadai, cakupan wilayah yang luas, dan terbatasnya kewenangan yang dimiliki oleh BNN Kabupaten Blitar. Penyelesaian hambatan pada upaya pemberantasan oleh BNN kabupaten Blitar antara lain bekerja secara bersama, penggunaan sarana pribadi pelaksana kegiatan, mengusulkan untuk penambahan personil, dan koordinasi rutin. (4) Indikator keberhasilan pencapaian kinerja BNN Kabupaten Blitar antara lain kesadaran dan kepedulain masyarakat di Kabupaten Blitar tentang bahaya narkoba, peran masyarakat dalam meningkatkan daya tangkal terhadap pengaruh buruk penyalahgunaan Narkoba di Kabupaten Blitar, adanya kepercayaan masyarakat terhadap BNN Kabupaten Blitar.

\section{DAFTAR PUSTAKA \\ BUKU-BUKU:}

Adisaputro, Gunawan. 2003. Anggaran Perusahaan. Edisi Pertama. BPFE Universitas Gajah Mada. Yogyakarta.

Anwas, Oos M, 2013, Pemberdayaan MAsyarakat di Era Global, Bandung. Alfabeta.

Arifin, Burhan. 2007. Narkoba dan Permasalabnnya. Semarang: PT. Bengawan Ilmu.

BNN. 2017. Narkoba dan Permasalabnnya. Jakarta

Ma'roef, M Ridha. 1986. Narkotika Masalab dan Bahayanya. Jakarta: CV. Marga Djaya.

Makarao, Moh Taufik, dkk. 2003. Tindak Pidana Narkotika. Jakarta: Ghalia Indonesia.

Moleong, Lexy J. 2006. Metodologi Penelitian Kualitatif. Bandung: PT Remaja Rosdakarya.

Mukti Fajar ND, dan Yulianto Achmad, 2006. Dualisme Penelitian Hukum Normatif \& Empiris. Yogyakarta: Pustaka Pelajar. 
Partodiharjo, Subagyo. 2008. Kenali Narkoba dan Musubi Penyalahgunaannya. Jakarta: Erlangga.

Prodjohamidjojo, Martiman. 1988. Pembahasan KUHAP dalam Teori dan Praktek. Jakarta: Pradya Paramita.

Sasangka, Hari. 2003. Narkoba dan Psikotropika dalam Hukum Pidana. Bandung: Mandar Maju.

Sofyan, Ahmadi. 2007. Narkoba Mengincar Anak Anda. Jakarta: PT. Prestasi Pustakarya.

Sudijono, Anas. 2004.Pengantar Statistik Pendidikan. PT Raja Grafindo Persada. Jakarta.

Sugiyono. 2011. Metode Penelitian Kuantitatif, Kualitatif dan R\&D.Bandung: Afabeta.

\section{PERUNDANG-UNDANGAN}

Undang-Undang No. 35 Tahun 2009 tentang Narkoba

Peraturan Presiden Republik Indonesia No. 23 Tahun 2010 tentang Badan Narkotika Nasional

Peraturan Kepala Badan Narkotika Nasional No. 3 Tahun 2015 tentang Organisasi Dan Tata Kerja Badan Narkotika Nasional Provinsi Dan Badan Narkotika Nasional Kabupaten/Kota

Peraturan Kepala Badan Narkotika Nasional No. 7 Tahun 2015 tentang Rencana Strategis Badan Narkotika Nasional Tahun 20152019

\section{INTERNET}

Denhura, Farida. BNN Ajak Mahasiswa Baru Berantas Narkoba, (http://ipk.sinarharapan.co/ipk/read/14 0916028/-span-span-bnn-ajak-maasiswabaru-berantas-narkoba-span-span), diakses tanggal 3 Januari 2018.

Faishol, Anas. P4GN Kabupaten Blitar Giat Perangi Narkoba (On Line). (https://www.blitarkab.go.id/2017/08/ 21/p4gn-kabupaten-blitar-giat-peranginarkoba/). Diakses pada 20 Oktober 2017.

Felisiani, Theresia. Kerjasama POLRI-BNN Dalam Berantas Narkoba Harus Efektif dan Efisien (http://www.tribunnews.com/nasional/ 2014/02/05/kerjasama-polri-bnndalam-berantas-narkoba-harus-efektifdan-efisien), diakses tanggal 3 Januari 2018.

KBBI. Peran (On Line). (http://KBBI.web.id). Diakses pada 29 Oktober 2017.
Kurniawan, Dian. Gawat, 20 Persen Pelajar Jatim Pengguna Narkoba (On Line). (http://regional.liputan6.com/ read/303 5104/gawat-20-persen-pelajar-jatimpengguna-narkoba). Diakses pada 29 Oktober 2017.

Suparman, Fana. Rehabilitasi dan Pencegaban, Indikator Sukses BNN (On Line). (http://www.beritasatu.com/aktualitas/ 183677-rehabilitasi-dan-pencegahanindikator-sukses-bnn.html). Diakses 20 Oktober 2017.

Hani. Darurat Narkoba, Senkom Dibekali Pelatihan Narkoba,

(http:/ /www.radarkedu.com/2015/05/2 6/darurat-narkoba-senkom-dibekalipelatihan-bnn/), diakses tanggal 3 Januari 2018. 